\title{
Grundtvig på tysk, Schriften in Auswahl
}

\section{Af Jørgen Kjaer}

Knud Eyvin Bugge, Theodor Jørgensen und Flemming LundgreenNielsen (udg.), N. F. S. Grundtvig: Schriften in Auswahl, Göttingen: Vandenhoeck \& Ruprecht, 2010.

Dette 942 sider lange, kommenterede udvalg af Grundtvigs skrifter i tysk oversættelse falder i tre hovedkapitler - kaldet: 1: Historischpoetische Schriften, 2: Pädagogische und politische Schriften, 3: Pädagogische und kirchliche Schriften. Et repræsentativt udvalg af Grundtvigs lyrik bringes dels i selvstændige afsnit i første bind under titlerne Weltliche Gedichte og Kirchen- und Bibellieder, hvor udvalget givetvis især har taget hensyn til digtenes poetiske kvaliteter, og dels rundt omkring $\mathrm{i}$ de to følgende bind $\mathrm{i}$ tematisk sammenhæng med prosaskrifterne, hvis pointer de bidrager til at illustrere. I forhold til for eksempel Borups og Schrøders håndbog, der inddeler Grundtvigs skrifter i skoletanker, kirkelige tanker og folkelige tanker, er der her foretaget mere subtile kategoriseringer, der fremhæver den tætte sammenhæng mellem det historiske og det poetiske - sådan som Grundtvig selv så det i indledningen til Nordens Mythologi - og mellem det praktisk-politiske og det pædagogiske, samt peger på Grundtvigs særegne, men yderst elaborerede og konstruktive kombination af adskillelse og sammenhæng, når det gælder forholdet mellem kirke og skole. De lyriske islæt gennem alle tre bind formidler et stærkt indtryk både af poesiens afgørende betydning for og allestedsnærværelse $\mathrm{i}$ forfatterskabet og understreger den nære sammenhæng mellem alle aspekter af Grundtvigs syntetiserende, integrative og vidtfavnende tænkning.

Foruden de oversatte tekster af Grundtvig rummer værket et forord af professor Dietz Lange, Göttingen, der har haft til opgave at bringe teksterne i overensstemmelse med den nye tyske retskrivning, en fortegnelse over de mange højt meriterede medarbejdere, der har medvirket som konsulenter og oversættere, et miniportræt af Grundtvig, en oversigt over de centrale historiske begivenheder i hans levetid samt over Grundtvigs liv og værker. Værket afsluttes med et personregister.

I betragtning af Grundtvigs omfattende og mangesidede forfatterskab har det ikke være nogen nem opgave at udvælge de forholdsvis få skrifter, der er blevet plads til. Ikke mindst har det naturligvis været svært at udvælge de poetiske værker, der skulle med, i betragtning af 
det overvældende antal højlødige digte, Grundtvig har produceret. Det smerteligste offer er fravælgelsen af det både poetisk enestående og for indsigten i Grundtvigs åndelige udvikling og selvforståelse centrale digt Nyaars-Morgen, som ganske er udeladt. At det ikke har kunnet medtages i sin fulde længde, giver sig selv, men de centrale strofer, hvor Grundtvig med både intellektuel skarphed, hudløs ærlighed og poetisk fyndighed gør op med sin ungdoms rationalistiske hovmod og narcissistiske selvoptagethed med ord som: "Da lærde jeg Arme, / I Midvinter sval, / At Lys uden Varme, / Er Helvedes Kval; / (...) Jeg kæmpe mig vilde / Til Kjærligheds-Kilde, / Omskabe jeg vilde mig selv!" (Nyaars-Morgen 1824, 21; jf. US IV, 261), kan stå for sig selv.

Princippet om at gengive tekster i deres helhed har også voldt vanskeligheder ved udvælgelsen af de historiske tekster. Da udgiverne i høj grad betoner Grundtvigs indsats og kvalifikationer som historiker, har disse skrifter en selvfølgelig plads i udgivelsen, hvorfor man her har fraveget helhedsprincippet og bragt uddrag af Kort Begreb af Verdens Krønike (1814) og Haandbog i Verdens-Historien (1833). En central tekst, der, om jeg så må sige, også er kommet til kort på grund af sin længde, er foredragene Mands Minde. Der bringes kun to meget korte uddrag, hvoraf det sidste omhandler spørgsmålet om faren ved Tysklands samling. Her peger Grundtvig på risikoen for, at denne vil føre til fremkomsten af en "uhyre tysk Krigsmaskine", der både vil være ødelæggende udadtil og indadtil (561) - profetisk tale. Hvad angår disse foredrag, har udgiverne dog en god grund til udeladelsen, for et fyldigt udvalg er allerede tilgængeligt på tysk i Johannes Tiedjes to-binds udgave fra 1927 N. F. S. Grundtvigs Schriften zur Volkserziehung und Volkheit, Jena, 1927.

Hvad angår teksternes rækkefølge inden for de tre bind, brydes også her to principper, et kronologisk og et tematisk. Ved at sammenstille tekster med samme tematik fra forskellige perioder opnår udgiverne, at læseren både får et indtryk af Grundtvigs tankemæssige udvikling og får skærpet blikket for både grundpointerne og kompleksiteten i hans tankeverden.

At formidle Grundtvig til en tysk offentlighed via en oversættelse af udvalgte skrifter er en opgave, der er lige så frygtindgydende, som den er vigtig $i$ en dansk-tysk kulturformidlingssammenhæng, og da opgaven er løst på noget nær forbilledlig vis, kalder denne kulturbedrift både på ærefrygt og taknemlighed. Her er der på basis af højeste fagkompetence blevet arbejdet med både pietet over for den store mand, videnskabelig akribi og kritisk nøgternhed, og der har tydeligvis udfoldet sig et tæt og tidkrævende samarbejde mellem oversætterne og udgiverne. 
Der synes at herske en slags konsensus om, at Grundtvig - især hans poesi - i princippet er uoversættelig. Vanskelighederne ved at oversætte Grundtvigs poesi til tysk er ikke mindst af stilistisk art, men der er også andre problemer. Hvad angår de teologisk og filosofisk reflekterende prosatekster, hvor Grundtvig prøver at forklare sine almene grundsynspunkter rationelt, dvs. logisk og begrebsligt, er det næppe sprogdragten, der udgør den største vanskelighed, for disse teksters sproglige form ligger på nogle områder tættere på en endnu levende tysk akademisk end på en moderne dansk akademisk tradition, der normalt $\mathrm{i}$ noget højere grad bestræber sig på at tage hensyn til forståelighed i en bredere offentlighed. Det "tyske" ved Grundtvigs stil er blandt andet hans vildtvoksende hypotaktiske sætningskonstruktioner og hans mange underforståede intertekstuelle referencer, der forudsætter store teologiske, litterære, filosofiske og historiske forkundskaber hos læseren. Her er det i høj grad den lærde og tyskpåvirkede humanist, der skriver, og ikke så meget folkeoplyseren, selvom Grundtvig tydeligvis bestræber sig på også at imødekomme et bredt publikum og søger at undgå det alt for lærde og docerende ved brug af folkelige talemåder, humor, selvironi og ved sparsom brug af fremmedord. Det er ikke mindst det meget høje vidensniveau, som Grundtvigs prosatekster forudsætter hos læseren, der gør dem svært tilgængelige. Denne digterpræst, som mere end noget anden lagde vægt på folkelighed og ikke bare nåede bredt ud til folket med sit budskab som digter og folketaler, men ind til marven af folkesjælen, fordi han lyttede til og studerede folkets sprog og gjorde sig de største anstrengelser for at (gen)tilegne sig det, han taler i mange af sine prosaskrifter i vid udstrækning hen over hovedet på folket. Men det hænger naturligvis sammen med, at han indretter sin stil efter adressaterne. Når han henvender sig til sine lærde standsfæller som teolog, humanist og/eller filosof, træder hensynet til det brede publikum i baggrunden. Paradoksalt nok kan man sige, at han i disse skrifter heller ikke tog meget hensyn til sit lærde publikum, som han ideligt udtrykte sin foragt for, han tvivlede også stærkt på, at hans lærde kolleger havde nogen som helst vilje til at forstå, hvad han sagde. Hvad de imidlertid ikke kunne undgå at forstå, var hans foragt for og had til både den boglige drengevidenskab, den universitære teologi og den tyskorienterede dannelse. Man kunne ikke overhøre hans udsøgte hån mod filosofiske og pædagogiske skolemestre og skriftkloge eksegeter, der repræsenterede et nyt pavedømme værre end det romerske. Det har ikke været nemt for datidens lærde koryfæer at stå model til Grundvigs spot, selvom det - i hvert fald siden Goethes Faust - har hørt til dagens orden, at boglærde mennesker har måttet 
døje de store ånders hån, spot og latterliggørelse. Her skal man nok også finde grunden til den uvilje, der har hersket og stadigt hersker på lærdommens højborge, mod overhovedet at beskæftige sig med Grundtvigs tanker og skrifter: de virker anstødelige på klassisk dannede lærde og humanister. Det var ikke uden grund, professor Clausen følte sig injurieret, og man kunne frygte, at Grundtvigs spydigheder i dag virker dobbelt anstødelige på dannede tyskere, for ikke bare spotter Grundtvig - selv funderet i et lærdomsniveau, der overgår, hvad de fleste klassisk dannede tyskere kan præstere - den fælleseuropæiske latinsk-humanistiske lærdomstradition, men også den nyhumanistiske og idealistiske tyske dannelsestænkning, ja den tyske ånd generelt. Det kan godt blive for meget for en dannet tysker, også selvom de selv måtte være kritiske over for de autoritære og elitære træk i den tyske uddannelses- og dannelsestradition.

Disse barrierer for forståelsen, som altså ikke kun er af sproglig art, stiller store krav til kommenteringen - ikke blot skal mere eller mindre skjulte referencer ekspliciteres, men den aktuelle historiske og politiske kontekst, teksterne er opstået i og taler ud fra og ind i, skal også forklares, ligesom man skal modvirke, at centrale dele af Grundtvigs anskuelser alt for hurtigt forstås ud fra fordomme og afværgemekanismer, der enten giver sig af Grundtvigs latterliggørelse af boglig lærdom eller af gamle misforståelser, der skyldes mangelfuldt kendskab til Grundtvigs tekster, eller også af nazismens fordærvelse af forestillingen om folkelighed og dens ideologiske udlægning af bondens rodfæstethed i den hjemlige muld. Her har udgiverne sandelig været på arbejde, men det forekommer mig, at de har løst opgaven på fremragende vis og fundet en mellemproportional mellem over- og underforsyning med kommentarer og holdt sig til det især for et tysk publikum væsentlige.

Særlige vanskeligheder har naturligvis oversættelsen af Grundtvigs poetiske værker frembudt, og her er det rigtig nok det sprogligt stilistiske, der volder vanskeligheder. Udgiverne er sig bevidst, at der nødvendigvis må gå noget tabt i oversættelserne, og for at kompensere for dette har de til benefice for danskkyndige tyskere valgt at bringe de danske originaltekster sideløbende med de tyske oversættelser, men dermed kommer det jo også til at springe i øjnene, hvor meget der går tabt. Det fremgår af udgivernes forord, at oversættelserne har været igennem en meget omstændelig redaktionsproces, hvor et panel af konsulenter har rådgivet i flere faser. Det bærer oversættelserne også præg af: man mærker både medarbejdernes omtanke, omhu og ildhu, det er bemærkelsesværdigt, hvor stor opfindsomhed der udfoldes for at få mening, poetisk udtryk, rim og rytme til at gå op i en højere enhed. Det særlige i Grundtvigs poesi er imidlertid så unikt og så tæt 
forbundet med hans specielle evne til at forene de mest heterogene komponenter som for eksempel "det østerlandske Billed-Sprog", det jævne, folkelige dagligsprog, barnlige udtryk og hjemlige, fortrolighedsskabende naturbilleder samt elementer fra den nordiske mytologi. Grundtvig råder over en rigdom af stilistiske virkemidler, der på hver deres vis bidrager til at skabe atmosfære og stemninger, der spænder fra den mest sublime glæde til den dybeste eksistentielle smerte, dødsangst og fortvivlelse. Det synes plat umuligt at genskabe Grundtvigs altid overraskende spændings- og farverigdom i oversættelserne. Problemet er ikke, at der ikke findes en lyrik med folkelig tone i Tyskland, og slet ikke, at der ikke findes en rig tysk salmetradition, der øser af samme bibelske kilder som Grundtvig, men det er spændvidden og spændstigheden, den utrolige variationsrigdom i stilen, det kniber med at gengive. Generelt sker der en homogenisering af det heterogene dels i retning af en klassisk-romantisk lyrisk tone og dels i retning af en traditionel tysk salmetone. Denne udglattende tendens kan illustreres ved oversættelsen af ét af Grundtvigs stærkeste digte: At sige Verden ret Farvel (222)

\section{Oversættelse:}

At sige Verden ret Farvel, I Livets Gry og Livets Kveld Er lige tungt at nemme, Det lærdes aldrig her paa Jord, Var, Jesus, ei du i dit Ord Hos os, som du er hjemme!
Recht Abschied nehmen von der Welt ob früh, ob spät, gleich schwer es fällt, damit vertraut zu werden; man lernt' es nie an diesem Ort, wärst du nicht, Jesus, in dein'm Wort auch hier bei uns auf Erden!

Man ser, at oversætteren her har gengivet meningen meget præcist samtidig med, at det lykkes at få versene til at rime og rytmen til at passe. Men der er rigtignok også faldet noget af i svinget: som rim på "Wort" har oversætteren valgt "Ort", da ordet "Erde" jo ikke opfylder rimkravet, dermed misses det prægnant pointerende i det danske rims kontrastering af det jordiske og det åndelige, der er knyttet til Jesu levende ord. Til gengæld făr oversætteren behændigt anbragt jorden $\mathrm{i}$ sidste verslinje, hvor "Erden" smukt rimer på "werden", men nu er der ikke længere nogen poetisk kraft i ordet, hverken som rimende kontrastord eller i forhold til den sidste verslinje i det danske forlæg, for udtrykket "hier bei uns auf Erden" er en ren kristelig kliché i forhold til forlæggets "som du er hjemme", der ikke på forhånd møder op med traditionelle kristelige konnotationer, men til gengæld ånder fortrolighed og nærhed på et rent menneskeligt plan og i øvrigt, som mange af Grundtvigs udtryk, svæver i en ejendommelig syntaktisklogisk flertydighed. 
I tredje strofe skriver Grundtvig:

Oversættelse:

\section{O Jesus, Herre, Broder sød!}

Du kiender bedst den bittre Død
O Jesus, Bruder in der Not!

Du kennst ja selbst den bittren Tod,

Også her er meningen ramt præcist, og rimet "Not-Tod" er jo i og for sig ganske logisk og meningsfuldt, for det menneske, der her henvender sig til Frelseren, er så sandelig i den dybeste nød netop på grund af tanken om døden, det stråler ud af alle digtets porer. Ikke desto mindre er udtrykket "Bruder in der Not" blegere, mere tamt og abstrakt end Grundtvigs udtryk "Broder sød", og de to verslinjer fremtræder som helhed mere glatte end forlægget, også her er for eksempel kontrasten i rimene forsvundet. Godt nok kan man sige, at ordet "sød" er så fortærsket, at man kunne betragte det som en dyd at undgå det, men i konteksten formidler ordet sammen med andre jævne udtryk for stærk bevægelse ikke sødladenhed eller pietistisk føleri, men den fortvivledes indtrængende og barnlige appel til Frelseren. Snarere end at sovse følelsen ind i et sødladent udtryk og smage på den skræller Grundtvig i dette digt masken og forsvarsværkerne væk og kommer ind til den nøgne gru ved tanken om "hvor mørkt der er i Graven" og formidler den druknendes længsel efter redning. Digteren taler som det fortvivlede barn til sin mor og får dermed udtrykt netop den dybe eksistentielle nød, som det floskelprægede tyske "Bruder in der Not" slet ikke formår at suggerere, selvom det gengiver meningen præcist og rimet "Not-Tod" understøtter denne gode, men netop alt for friktionsløse, mening.

Også i strofe 4 volder Grundtvigs specielle barnlige udtryksmåde problemer:

Sidste halvdel af strofen lyder på tysk:

$\mathrm{O}$, kom du, som engang, jeg veed,

Du i din Faders Herlighed

Skal klart dig aabenbare,

Var det i Gry, var det i Kveld,

der Abschied fiele leichter mir;

Jeg skyndte mig, med kort Farvel, I Sky til dig at fare! ob früh, ob spät, ich würd' zu dir sogleich gen Himmel fahren!

Hele sekvensen er mere abstrakt og farveløs end Grundtvigs både folkeligt dagligsprogprægede, barnlige og malende.

I betragtning af, at Grundtvigs virkning i en dansk kontekst - som det også fremhæves af udgiverne - i høj grad skyldes hans digtning, er 
det selvfølgeligt fatalt $\mathrm{i}$ en interkulturel formidlingssammenhæng, at det ikke synes muligt at gengive det, der skaber Grundtvigs særegne poetiske magi. Men man kan jo ikke laste oversætterne for, at de ikke har gjort det umulige, de har netop gjort det bedst mulige, idet de har ramt meningen meget præcist og samtidig på opfindsomste vis kombineret den med forlæggenes versemål og rimskema. Jeg har fundet meget få eksempler på oversættelser, der er skæve i forhold til meningen, som når for eksempel det danske ord "Eftermælet" i digtet Moders Navn er en himmelsk Lyd bliver til det tyske "Ruhm, der bleibet" (519).

Denne på alle måder særdeles gennemarbejdede og velkommenterede udgivelse, som de tre udgivere har arbejdet på i 25 år assistereret af et panel af højtkvalificerede konsulenter, opfylder i den grad et desideratum i den dansk-tyske kulturdialog. I betragtning af hvor megen inspiration Grundtvig har hentet fra tysk åndsliv, og i hvor høj grad han udvikler sin tænkning i et opgør med nogle til dels skæbnesvangre tendenser i tysk tænkning, og i betragtning af, at Grundtvigs skoletanker har haft betydning for tysk pædagogik især i form af oprettelse af en del Heimvolkshochschulen, er det påfaldende beskedent, hvad der tidligere har været oversat. Den hidtil eneste større samling af Grundtvigtekster på tysk er førnævnte Johannes Tiedjes udvalg fra 1927. Hvad der derudover foreligger på tysk, er et beskedent antal salmer samt enkelte prosatekster. En fortegnelse over tyske oversættelser af tekster af og om Grundtvig kan findes i E. Harbsmeiers bibliografi over Grundtvig-litteratur på ikke-skandinaviske sprog i Thodberg, C. (ed.) N. F. S. Grundtvig Tradition und Erneuerung, København 1983, 452 f.

De enkelte bind indledes som sagt med korte indledninger, hvor Grundtvigs tanker og virksomhed inden for de respektive områder trækkes op, og den modne Grundtvigs hovedpointer profileres. Det er gjort så godt, at man kunne ønske, at de blev oversat til dansk og publiceret som en selvstændig introduktion til Grundtvigs liv og forfatterskab. En sådan publikation ville ikke bare være nyttig for de mange danskere, der ligesom tyskerne ikke kender meget til Grundtvigs skrifter, men også for folk, der som undertegnede har forsøgt at sætte sig ind i Grundtvigs tankeverden, men ofte løber vild i dette fantasifulde og paradoksale univers, hvad enten det nu skyldes det forhold, at Grundtvig hele tiden udvikler sig og gør op med tidligere positioner, eller det skyldes, at det menneskeliv, Grundtvig søger at udgrunde, i sig selv er så fuld af selvmodsigelser og hemmelighedsfulde dunkelheder, at det nødvendigvis må forplante sig til de fortolkninger, man underkaster det, eller at Grundtvig ikke er nogen 
stringent tænker - eller alle tre ting og meget mere. Hvorom alting er, man får i disse indledninger et klargørende indblik både i Grundtvigs centrale tankemæssige pointer, hans poetiske produktion, hans indsats inden for pædagogik og politik og hans teologiske tænkning, og man får et godt indtryk af, hvorledes Grundtvig udvikler sin tænkning og sin poetiske produktion $i$ en lang proces og i stadigt livtag med tidens udfordringer og i konflikt med tidens smagsdommere, og man făr også i nogen grad klargjort, hvor uklarhederne, selvmodsigelserne og inkonsekvenserne gemmer sig.

Indledningerne tegner generelt et særdeles positivt billede af en frisindet digter, politiker og præst, der bestræbte sig på at fremme en oplysning, der står i menneskelivets, frihedens, folkets og menneskehedens tjeneste. Den modne Grundtvigs anskuelse "Menneske først og Christen så" står helt centralt. Men billedet er trods sin "partiskhed" (i Grundtvigs egen forstand) ikke ensidigt harmoniserende og idealiserende. I indledningen til Grundtvigs teologiske skrifter peges der for eksempel på en uklarhed, ambivalens eller selvmodsigelse i Grundtvigs bestemmelse af forholdet mellem en folkelig kirke, hvor folkeligheden og folkeånden optræder som en individualiseret udgave af Helligånden, og på den anden side Gudsfolkets kirke, hvor ikke folkeånden, men Helligånden, er centrum og drivende kraft. Der lægges ikke skjul på, at den folkeåndelige udgave af kristendommen rummer faren for at skride ud i en ekskluderende nationalistisk kristendom, og at Grundtvig indimellem faktisk lå under for denne fare og betragtede danskerne som et udvalgt folk (642). Der kunne nok være boret mere i denne ambivalens eller selvmodsigelse, da det præcist er den, som åbner for misbrug af Grundtvig og samtidig giver anledning til skepsis over for Grundtvigs angivelige frisind og inklusivitet, en skepsis, der har fundet sit hidtil mest radikale udtryk i Inga Meinckes doktorafhandling Vox viva. Die "wahre Aufklärung" des Dänen Nikolaj Frederik Severin Grundtvig, Heidelberg, 2000. Her ses Grundtvig konsekvent som det stik modsatte af det, han giver sig ud for, og som han generelt opfattes som her i landet: Grundtvig er hverken en frisindets eller en oplysningens mand, men en åndelig terrorist og "Gegenaufklärer" - en mørkemand og patologisk narcissist. Det ville jo være dejligt at kunne affærdige Meinckes værk som udtryk for tysk fordomsfuldhed og mangel på indsigt i Grundtvigs værker. Desværre forholder det sig ikke sådan; tværtimod har hun sat sig ualmindeligt grundigt ind i Grundtvigs tekster og tankeverden og argumenterer, trods sin monumentale énsidighed, der for eksempel gør hende blind for, at Grundtvig allerede i sin ungdom erkendte og gjorde op med sin narcissistiske selvoptagethed, særdeles skarpsindigt for sine synspunkter. Den tyske litteraturprofessor Heinrich Detering, som an- 
meldte værket i Frankfurter allgemeine Zeitung (9.8.2001), anerkender da også afhandlingens høje niveau, på trods af, at han selv er en stor beundrer af Grundtvig og peger på Grundtvigs "Vision eines Landes freier und sozial gleichgestellter Bürger" og er ganske uenig med Meincke i hendes dæmonisering af Grundtvig.

I det hele taget udspiller den moderne tyske debat og den danske tyske dialog om Grundtvig sig på et særdeles højt og for det meste konstruktivt niveau, hvilket man kan forvisse sig om ved at blade i to Grundtvigantologier fra 1980'erne: Thodberg, C. og Pontoppidan Thyssen, A. (ed.), N. F. S. Grundtvig - Tradition und Erneuerung. Grundtvigs Visionen von Mensch, Volk, Erziehung und Kirche und ihre Bedeutung für die Gegenwart, København, 1983 og Röhrig, P. (ed.), Um des Menschen willen. Grundtvigs geistiges Erbe als Herausforderung für Erwachsenenbildung, Schule, Kirche und soziales Leben, Weinheim, 1991.

Diskussioner som den mellem Meincke og Detering og den nye Grundtvigudgaves påpegning af modsigelsen mellem Grundvigs frisind, åbenhed og økumenisk-universalhistoriske horisont på den ene side og hans bornerte nationalisme og hang til xenofobisk afstandtagen fra det fremmede - især det tyske - og til heroisering af dansken og hans kæmpeånd på den anden side, lægger op til dybere ransagning af det også i dag højst brisante spørgsmål om, hvor grænsen går mellem berettiget naturlig kærlighed til fædreland og modersmål og xenofobisk eksklusivitet, mellem frisindets medmenneskelighed og åbenhed over for det andet og fremmede og den naivt multikulturalistiske accept af alt det fremmede - også de fremmedes intolerance - på den anden side, mellem patologisk narcissistisk og fundamentalistisk selvophøjelse til profet og folkefører og den ydmyge, men karismatiske åndelige vejleder. Her er stærke kræfter og modsætninger på spil, og det forholder sig ikke kun sådan, at det ene nødvendigvis hidrører fra noget højere og åndeligt og det andet fra noget lavere og driftsmæssigt. Også ånd kommer af drift, og det åndelige er selv en umådelig stærk drift, som kan slå over i dæmoni, når den forbindes med individets stræben efter magt. Selv Jesus måtte gribe til eksorcistiske besværgelser, da han blev fristet i ørkenen, og Fanden besatte som bekendt til tider både Luther og Grundtvig. Ikke sært, at Grundtvig lagde så stor vægt på forsagelsen af djævelen og alle hans gerninger. Når Grundtvig rager så højt op, skyldes det blandt andet, at han som mange andre poetiske genier havde kontakt med sit indre barn, men samtidig havde han også kontakt med sindets og verdens ubevidste og farlige kræfter, og han var meget bevidst om disse kræfters styrke og farlighed. Han er i slægt med shamaner og 
troldmænd, der har særlig kontakt med de usynlige magter og forstår at omgås dem, således at deres potentielt skadelige kræfter vendes til velsignelse for folket. I denne atavistisk-gammeltestamentlige forstand er han også en profet. Men det er svært at forstå, hvordan sådan noget er muligt - endda i en moderne verden. Men måske er grænsen mellem de skadelige og de frugtbare kræfter, mellem det atavistisk-primitive og det sublimt åndelige hårfin. Thomas Mann, som var meget optaget af sammenhængen mellem de dunkle chtoniske magter og de lyse og velsignelsesrige, skrev i 1938 et essay med titlen Bruder Hitler, hvor han ser et slægtskab mellem skabende kunstnere som Wagner og sig selv og Hitlers "geni". I betragtning af hvordan de diabolske kræfter raser $i$ verden $i$ dag, hvad enten det er $i$ form af den vestlige verdens frisatte sex- og magtbegær og narcissistiske individualisme eller af islamistisk fundamentalisme, er det måske ikke det mindst interessante ved Grundtvig, at han er et mønstereksempel på, hvordan destruktive, dæmoniske kræfter brydes med livets og lysets kræfter, og efter min opfattelse også på, hvordan mørkets kræfter kan overvindes, uden at man i forsøget på at bekæmpe dem og forsage dem blot maner dem frem og styrker dem. Vilhelm Grønbech har i sin artikel om Kierkegaard og Grundtvig i bogen Kampen om Mennesket, København, 1930, nogle dybsindige og højst aktuelle tanker om denne kamp på liv og død mellem Kristus og Satan, hvoraf der igen og igen fødes en ny verden.

I denne nye udgivelse af et udvalg af Grundtvigs skrifter på tysk kan den vigtige diskussion om Grundtvig og al hans væsen, hvad enten den udspiller sig internt i Danmark og Tyskland eller som en interkulturel dialog, hente ny inspiration. 